\title{
Root mass vertical distribution of perennial cool-season grasses grown in pure or mixed swards
}

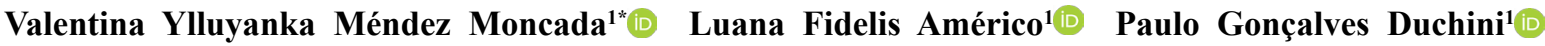 Gabriela Cristina Guzatti ${ }^{2}$ Daniel Schmitt ${ }^{1}\left(\mathbb{D}\right.$ André Fischer Sbrissia ${ }^{1}(\mathbb{D}$}

'Departamento de Produção Animal e Alimentos, Centro de Ciências Agroveterinárias, Universidade do Estado de Santa Catarina (UDESC), 88520-000, Lages, SC, Brasil. E-mail: valen1410@gmail.com. *Corresponding author.

${ }^{2}$ Instituto Federal de Santa Catarina (IFSC), São Miguel do Oeste, SC, Brasil.

ABSTRACT: In this study we tested whether the root biomass of mixtures composed by grass species is greater than their respective monocultures. The treatments were monocultures of Arrhenatherum elatius, Festuca arundinacea, Dactylis glomerata, and a mixture of them, cultivated in a rich-soil environment. Root biomass was evaluated on a single evaluation per season at three soil depths $(0-5,5-10$, and 10-20 $\mathrm{cm})$. Mixed swards presented the greatest root biomass, and this was explained by a greater concentration in the topsoil layer $(0-5 \mathrm{~cm})$. These findings reinforce the need for permanent soil conservation practices to not jeopardize the benefits of the more abundant root biomass reported in the mixed swards.

Key words: biodiversity, mixed cultivation, root system.

Distribuição vertical da massa de raízes de gramíneas perenes de inverno cultivadas puras e em mistura

RESUMO: O presente estudo testou se a biomassa radicular de misturas compostas por gramíneas é maior do que os seus respectivos monocultivos. Os tratamentos foram monocultivos de Arrhenatherum elatius, Festuca arundinacea, Dactylis glomerata e uma mistura delas, cultivadas em um solo rico em nutrientes. A biomassa da raiz foi avaliada uma vez por estação em três profundidades de solo (0-5, 5-10 e 10$20 \mathrm{~cm}$ ). Os pastos mistos apresentaram a maior biomassa radicular e isso pode ser explicado pela maior concentração de raízes na camada superficial do solo (0-5 cm). Esses achados reforçam a necessidade de práticas permanentes de conservação do solo para não prejudicar os beneficios da biomassa radicular mais abundante encontrada nos pastos mistos.

Palavras-chave: biodiversidade, cultivo misto, sistema radicular.

Increasing biodiversity in grasslands can maximize soil carbon incorporation (TRACY \& SANDERSON, 2000; TILMAN et al., 2006), boosting the ecosystem services delivered by pasturelands. As far as we are aware, most of the reported research on this topic has been focused on grasslands with plant species belonging to different families (Poaceae, Fabaceae, Cruciferae, and/or Asteraceae; MUELLER et al., 2013; CONG et al., 2014; SKINNER \& DELL, 2016) and little is known whether mixed stands composed only by grasses also present a greater root biomass production when compared to their respective monocultures. In this context, we assessed the root biomass across soil layers of pastures composed by monocultures of Arrhenatherum elatius, Festuca arundinacea, Dactylis glomerata, and a mixture of them, to test whether the root biomass of mixtures composed only by grass species is greater than their respective monocultures.

The study was conducted in Lages/SC, Brazil $\left(27^{\circ} 47^{\prime} \mathrm{S}, 50^{\circ} 18^{\prime} \mathrm{W}, 960 \mathrm{~m}\right.$ a.s.1.), between August 2015 and August 2016. According to the Köppen classification, the climate of the region is $\mathrm{Cfb}$ type (subtropical). The soil of the experimental area is classified as Typical Aluminum Humic Cambisol and presented the following characteristics $(0-20 \mathrm{~cm})$ : $\mathrm{pH}$ (SMP) 6.0; organic matter $1.4 \%$; Ca $6.31 \mathrm{cmolc} /$ $\mathrm{dm}^{3} ; \mathrm{K} 180 \mathrm{mg} / \mathrm{dm}^{3} ; \mathrm{P} 8.7 \mathrm{mg} / \mathrm{dm}^{3} ; \mathrm{Mg} 4.04 \mathrm{cmolc} /$ $\mathrm{dm}^{3} ; \mathrm{H}+\mathrm{Al} 4.6 \mathrm{cmolc} / \mathrm{dm}^{3}$; cation exchange capacity (pH 7.0) $15.4 \mathrm{cmolc} / \mathrm{dm}^{3}$, base saturation $70.2 \%$;

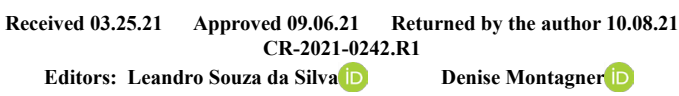


clay $46 \%$. Fertilizations were performed in order to maintain a rich-soil environment and nitrogen nutrition status above 0.8 (see AMÉRICO et al. 2021 for more information). The treatments were $A$. elatius 'Santa Vitoria', F. arundinacea 'Quantum II', and D. glomerata 'Ambar' sowed as monocultures and as mixture composed of the three species in the same proportions. These treatments were assigned across twelve $45-\mathrm{m}^{2}$ plots, following a complete randomized design. Information about plot management and weather data are in DUCHINI et al. (2019).

To determine root biomass, samplings were performed on a single evaluation per season (in November 2015, February 2016, May 2016, and August 2016) in two representative areas per plot using a steel cylinder (6-cm diameter x 20-cm deep). The core soil samples were separated into sub-samples according to the soil layer $(0-5,5-10$, and 10-20 cm), and taken to the laboratory to separate roots from soil by washing with running water. Subsequently, the root samples were dried in a forced-air oven at $65^{\circ} \mathrm{C}$ for $72 \mathrm{~h}$ and weighed.

The data were submitted to analysis of variance using the MIXED procedure of the SAS ${ }^{\circledR}$ (version 9.0). For the total root biomass, the model included the effects of treatment, season, and their interaction; the season was considered as repeated measurements and the Akaike information criterion (AIC) was used to select the best covariance matrix. For vertical distribution of the root biomass, data were analyzed separately by each soil layer within seasons; this was done to simplify the statistical analysis and focus the discussion on our main objectives. The means were compared by using the Student's t-test and the significance for all analysis was set at $10 \%(\mathrm{P}<0.10)$.

The total root biomass was affected by the cultivation $(\mathrm{P}=0.05)$ and season $(\mathrm{P}=0.02)$, but it was not observed an interaction between them $(\mathrm{P}=$ 0.21 ; Figure 1). In general, a lower root biomass was observed in the summer $\left(387 \mathrm{~g} / \mathrm{m}^{2}\right)$, whereas in the other seasons (autumn, winter, and spring) the values were higher and similar to each other (averaging $583 \mathrm{~g} / \mathrm{m}^{2}$; Figure 1B). Such a pattern of response is probably related to the demographic pattern of the studied species, as during the cool seasons (autumn and winter) the rate of appearance and survival of tillers are higher than in the warmer periods (spring and summer; DUCHINI et al., 2018). Regarding to the cultivation method, a greater root biomass was observed in the mixture $\left(655 \mathrm{~g} / \mathrm{m}^{2}\right)$ when compared to the monocultures (averaging $493 \mathrm{~g} / \mathrm{m}^{2}$; Figure 1A). As interspecific competition was probably restrained by the high input of fertilizers (AMÉRICO et al., 2021) and tiller population density was not greater in the mixture (DUCHINI et al., 2018), an alternative explanation for such greater root biomass in the mixture could be the species-specific root interaction. In this context, root growth and distribution would be modulated by the identity of the neighboring roots, and non-nutritious cues, such as root exudates (BAIS et al. 2006) or root rhizosphere biota (KARDOL et al., 2007), could be the mechanisms behind root recognition (MOMMER et al., 2010).

All treatments showed a decrease in root biomass across the soil layers (Table 1). In general,
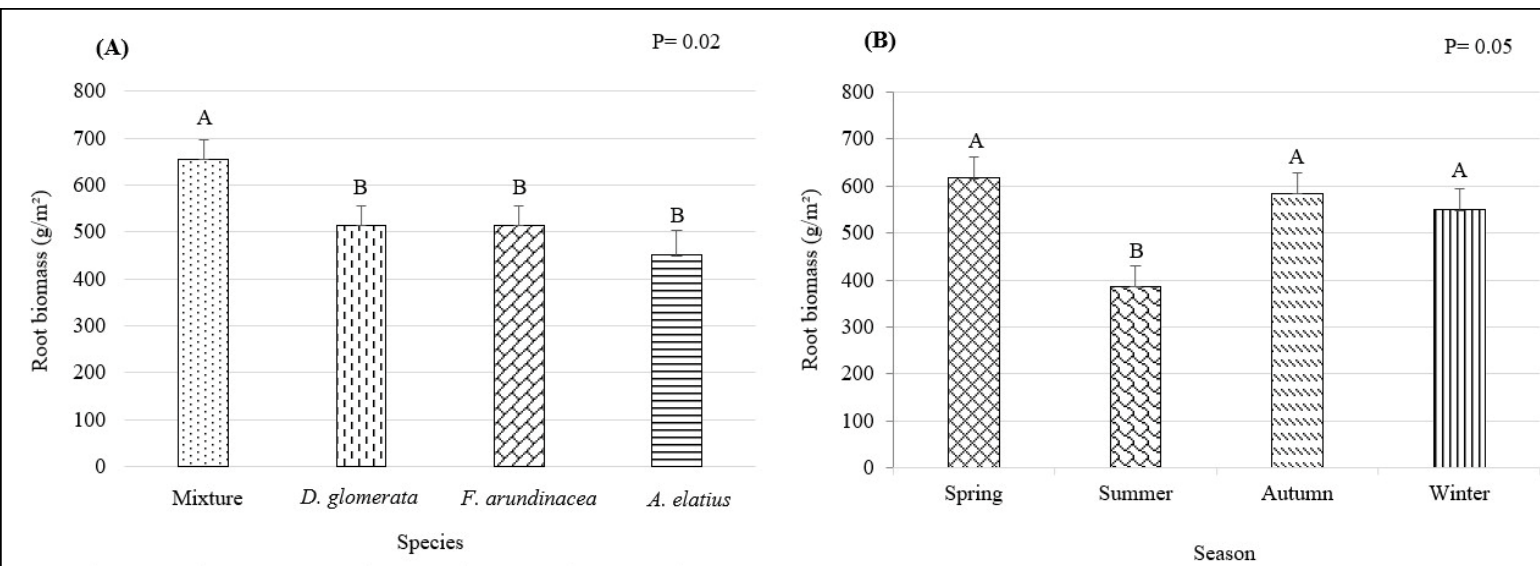

Figure 1 - Root biomass in pure or mixed pastures of Arrhenatherum elatius, Festuca arundinacea, and Dactylis glomerata (A) at different seasons (B). Means followed by the same letter do not differ by the Student's t-test $(\mathrm{P}>0.10)$. 
Table 1 - Vertical distribution of the root biomass $\left(\mathrm{g} / \mathrm{cm}^{2}\right)$ in pure or mixed pastures of Arrhenatherum elatius, Festuca arundinacea, and Dactylis glomerata across seasons.

\begin{tabular}{|c|c|c|c|}
\hline \multicolumn{4}{|c|}{--------------------------------------SSoil depth (cm)--------------------------------------- } \\
\hline Species & $0-5$ & $5-10$ & $10-20$ \\
\hline \multicolumn{4}{|c|}{ 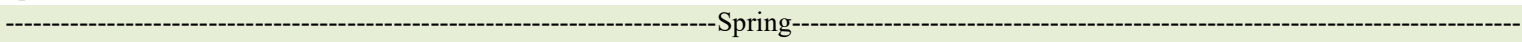 } \\
\hline Mixture & $665 \mathrm{~A}$ & $70 \mathrm{~A}$ & $45 \mathrm{AB}$ \\
\hline A. elatius & $387 \mathrm{~B}$ & $65 \mathrm{AB}$ & $45 \mathrm{AB}$ \\
\hline D. glomerata & $492 \mathrm{AB}$ & $43 \mathrm{~B}$ & $33 \mathrm{~B}$ \\
\hline F. arundinacea & $473 \mathrm{AB}$ & $78 \mathrm{~A}$ & $57 \mathrm{~A}$ \\
\hline SEM & \pm 80.4 & \pm 8.4 & \pm 1.3 \\
\hline \multicolumn{4}{|c|}{ 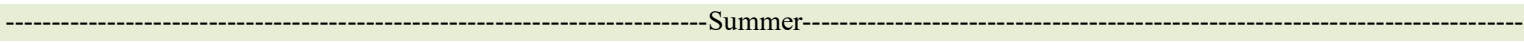 } \\
\hline Mixture & $281 \mathrm{~A}$ & $75 \mathrm{AB}$ & $52 \mathrm{~A}$ \\
\hline A. elatius & $243 \mathrm{AB}$ & $72 \mathrm{AB}$ & $65 \mathrm{~A}$ \\
\hline D. glomerata & $209 \mathrm{~B}$ & $57 \mathrm{~B}$ & $41 \mathrm{~A}$ \\
\hline F. arundinacea & $290 \mathrm{~A}$ & $88 \mathrm{~A}$ & $76 \mathrm{~A}$ \\
\hline SEM & \pm 27.9 & \pm 8.8 & \pm 14.1 \\
\hline \multicolumn{4}{|c|}{ 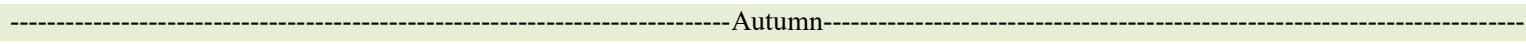 } \\
\hline Mixture & $618 \mathrm{~A}$ & $95 \mathrm{~A}$ & $56 \mathrm{BC}$ \\
\hline A. elatius & $180 \mathrm{~B}$ & $84 \mathrm{~A}$ & $65 \mathrm{AB}$ \\
\hline D. glomerata & $505 \mathrm{~A}$ & $60 \mathrm{~A}$ & $44 \mathrm{C}$ \\
\hline F. arundinacea & $476 \mathrm{~A}$ & $67 \mathrm{~A}$ & $80 \mathrm{~A}$ \\
\hline SEM & $\pm 7 ., 2$ & \pm 14.1 & \pm 5.9 \\
\hline \multicolumn{4}{|c|}{ 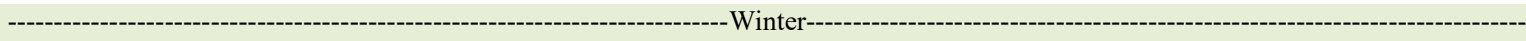 } \\
\hline Mixture & $517 \mathrm{~A}$ & $70 \mathrm{~A}$ & $52 \mathrm{~A}$ \\
\hline A. elatius & $440 \mathrm{~A}$ & $82 \mathrm{~A}$ & $74 \mathrm{~A}$ \\
\hline D. glomerata & $496 \mathrm{~A}$ & $46 \mathrm{~B}$ & $30 \mathrm{~B}$ \\
\hline F. arundinacea & $249 \mathrm{~B}$ & $81 \mathrm{~A}$ & $58 \mathrm{~A}$ \\
\hline SEM & \pm 51.4 & \pm 7.1 & 8.0 \\
\hline
\end{tabular}

${ }^{1} \mathrm{SEM}=$ Standard error of the mean. For each season, means followed by the same in the column letter do not differ by the Student's t-test $(\mathrm{P}>0.10)$.

the mixture presented a higher concentration of root biomass in the first $5 \mathrm{~cm}$ of the soil, but as the depth in the soil horizons increased $(5-10$ and $10-20 \mathrm{~cm})$, the values were similar to those of $F$. arundinacea and $A$. elatius $(\mathrm{P}=0.01)$. This response is relatively common in grasslands, where root mass is concentrated near the soil surface, with about $60-80 \%$ of the total root mass concentrated up to a depth of $15 \mathrm{~cm}$ (SKINNER $\&$ DELL, 2016). Moreover, we hypothesized that there were no stimuli to plants deepen their root system, as fertilization (AMÉRICO et al., 2021) and rainfall (DUCHINI et al., 2019) were not limiting during the experimental period.

In conclusion, mixed pastures composed only by grasses present a greater root biomass than their respective monocultures. However, the superior root biomass observed in the mixture was mainly due to an accumulation of roots in the topsoil layer $(0-5 \mathrm{~cm})$. These findings reinforce the need of permanent soil conservation practices, as non-tillage systems, to not jeopardize the benefits of the more abundant root biomass reported in the mixed swards. Finally, it should be evaluated this mixture for a longer period to identify whether the root systems could penetrate deeper in soil and; therefore, deliver more ecosystem services.

\section{ACKNOWLEDGEMENTS}

Thanks are due to conselho Nacional de Desenvolvimento Científico e Tecnológico (CNPq) for the financial incentive (CNPq, Grant no. 456394/2014-1), Fundação de Amparo à Pesquisa e inovação do Estado de Santa Catarina (FAPESC, Grant no. 2021TR813) and Coordenação de Aperfeiçoamento de Pessoal de Nível Superior (CAPES, Brazil).

\section{DECLARATION OF CONFLICT OF INTEREST}

We have no conflict of interest to declare. 


\section{AUTHORS' CONTRIBUTIONS}

All authors contributed equally for the conception and writing of the manuscript. All authors critically revised the manuscript and approved of the final version.

\section{REFERENCES}

AMÉRICO, L. F. et al. Nitrogen nutritional status in perennial grasses under defoliation: Do stubble height and mixed cultivation matter? Journal of Plant Nutrition and Soil Science, v.184, p.208-2016, 2021. Available from: <https://doi.org/10.1002/ jpln.202000201>. Accessed: Aug. 05, 2021. doi: 10.1002/ jpln.202000201.

BAIS, H. P. et al. The role of root exudates in rhizosphere interactions with plants and other organisms. Annual Review of Plant Biology, v.57, p.233-266, 2006. Available from: $<$ https://doi. org/10.1146/annurev.arplant.57.032905.105159>. Accessed: Aug. 05, 2021. doi: 10.1146/annurev.arplant.57.032905.105159.

CONG, W.F. et al. Plant species richness promotes soil carbon and nitrogen stocks in grasslands without legumes. Journal of Ecology, v.102, p.1163-1170, 2014. Available from: $<$ https://doi. org/10.1111/1365-2745.1228>. Accessed: Aug. 05, 2021. doi: $10.1111 / 1365-2745.1228$.

DUCHINI, P. G. et al. Experimental evidence that the perennial grass persistence pathway is linked to plant growth strategy. PLoS ONE, v.13, p.1-15, 2018. Available from: $<$ https://doi.org/10.1371/ journal.pone.0207360>. Accessed: Aug. 05, 2021. doi: 10.1371/ journal.pone. 0207360 .

DUCHINI, P. G. et al. Can a mixture of perennial grasses with contrasting growth strategies compose productive and stable swards? Agronomy Journal, v.111, p.224-232, 2019. Available from: <https://doi.org/10.2134/agronj2018.03.0218>. Accessed: Aug. 05, 2021. doi: 10.2134/agronj2018.03.0218.

KARDOL, P. et al. Microbe-mediated plant-soil feedback causes historical contingency effects in plant community assembly. Ecological Monographs, v.77, p.147-162, 2007. Available from: $<$ https://doi.org/10.1890/06-0502>. Accessed: Aug. 05, 2021. doi: 10.1890/06-0502.

MOMMER, L. et al. Unveiling below-ground species abundance in a biodiversity experiment: a test of vertical niche differentiation among grassland species. Journal of Ecology, v.98, p. $1117-1127,2010$. Available from: <http://doi.org/10.11 11/j.1365-2745.2010.01702.x>. Accessed: Aug. 05, 2021. doi: $0.1111 / \mathrm{j} .1365-2745.2010 .01702 . x$

MUELLER, K. E. et al. Root depth distribution and the diversityproductivity relationship in a long-term grassland experiment. Ecology, v.94, p.787-793, 2013. Available from: <https://doi.org/10.1890/121399.1>. Accessed: Aug. 05, 2021. doi: 10.1890/12-1399.1

TILMAN, D. et al. Carbon-negative biofuels from low-input high-diversity grassland biomass. Nature, v.314, p.1598-1600, 2006. Available from: <https://doi.org/10.1126/science.1133306>. Accessed: Aug. 05, 2021. doi: 10.1126/science.1133306.

TRACY, B.F.; SANDERSON, M.A. Patterns of plant species richness in pasture lands of the northeast United States. Plant Ecology, v.149, p.169-180, 2000. Available from: <https://doi. org/10.1023/A:1026536223478>. Accessed: Aug. 05, 2021. doi:10.1023/A:1026536223478.

SKINNER, R. H.; DELL, C. J. Yield and soil carbon sequestration in grazed pastures sown with two or five forage species. Crop Science, v.56, p.2035-2044, 2016. Available from: <https://doi. org/10.2135/cropsci2015.11.0711>. Accessed: Aug. 05, 2021. doi: 10.2135/cropsci2015.11.0711 